\title{
SHARK LONGLINE FISHERY IN TANJUNGLUAR-EAST LOMBOK
}

\author{
Dharmadi, Ria Faizah and Lilis Sadiyah \\ Research Center for Fisheries Management and Conservation \\ Received June 04-2012; Received in revised form May 03-2013; Accepted June 03-2013 \\ Email:darma_ancol@yahoo.com
}

\begin{abstract}
Studies on artisanal shark fisheries in Tanjungluar - East Lombok were conducted during the year 2001-2011 (except in 2003 and 2007). A sampling method called "rapid market survey" method was employed to collect catch data from surface and bottom longlines fishing, rapidly. Biological data and fisheries data were collected during survey. Catch data for shark were also obtained from daily records filled by TPI officers in Tanjungluar between 2009 and 2010. The results showed that shark longline fishing was conducted every month. The trend of shark catches relates to the number of fishing vessels, fishing ground, and weather conditions at sea. The period between July and September is a transitional season from East to West seasons. During this season, the wind strength is weakened and a good fishing season for the fishers. The lowest catch occurs in January (1.06 tonnes) and the highest catch in September with the total catch of 24.6 tonnes. Sharks caught by surface longline were dominated by Silky shark, Carcharhinus falciformis (40-90\%) with the size range of $100-125 \mathrm{~cm}$. The catch of bottom longline was mostly consisting of fish in mature condition that dominated by Grey reef shark (Carcharhinus amblyrhynchos), Common black tip shark (C. limbatus), Spot tail shark ( $C$. sorrah), and Scalloped hammerhead shark (Sphyrna lewini), with the size range of $125-200 \mathrm{~cm}, 170$ $250 \mathrm{~cm}, 100-150 \mathrm{~cm}$, and $170-300 \mathrm{~cm}$, respectively. Surface longline fishing occurs in the offshore waters in depth more than $200 \mathrm{~m}$ to $3000 \mathrm{~m}$, whereas bottom longline fishing is operated at a depth of $50-100 \mathrm{~m}$ around islands.
\end{abstract}

KEYWORDS: Shark, longline fishing, Tanjungluar, East Lombok

\section{INTRODUCTION}

Globally, it was estimated that more than $50 \%$ of elasmobranchii catches were caught as bycatch, but the catches were not recorded in the world fisheries statistics (Stevens et al., 2000). Based on the annual fisheries statistics, Indonesia has the highest catch of elasmobranchii in the world (Steven et al., 2000; Bonfil, 2008), or the highest from 1990 - 2008 among 20 countries (including Taiwan, Spain, Mexico and India) with production of 113,626 tonnes in 2000 and 107,290 ton in 2008 or $13.25 \%$ of the global catch (Lack \& Sant, 2011), and export value of $\$ 13$ billion (Blaber et al., 2009). The record of catch in national level includes target and by-catch. Blaber (2006) estimated that $16 \%$ of total shark landed in Indonesia was by-catch, and it was estimated to have increased up to $32 \%$ in 2010 (Zainudin, 2010).

The main problem in the Indonesia's shark fishery is that the catch data are not broken down into species, they are mixed together into one category. In Nusa Tenggara Timur, some fishers only take the shark fins and if their catch exceeding their target the alive shark were then released to the sea.

To date, shark exploitation is without control, the fishers aim to catch shark as much as possible, which could threaten its population. Meanwhile, biological characteristics of shark include long duration of pregnancy, slow growing, long lived species, low fecundity and produce relatively small number of young. They are very vulnerable to extinction under high fishing pressure (Sylvana et al., 1998; Castro et al., 1999).

To prevent a drastic decrease in shark population, a proper management is required. Information on the fisheries and the biology of shark is needed as a basis in the development of management. Tanjungluar, in East Lombok, West Nusa Tenggara Province is a fishing base for shark fisheries. Within this area, sharks were caught as a main target species in the bottom and surface longline fisheries. This paper provides description of fishing gear, fishing ground, species composition, and monthly catch, and dominant shark catches.

\section{MATERIALS AND METHODS}

Astudy was conducted in Tanjungluar Fish Landing Place (called as Tempat Pendaratan lkan/TPI), a main landing place for shark located in East Lombok, West Nusa Tenggara. Shark data were collected in the framework of "rapid market survey" method, i.e. recording catch data from surface and bottom longlines fishing, rapidly, during the survey. 
The field trip was undertaken for 151 days, between April 2001 and Februari 2011. Data collected include biological data (sex and total length, length of clasper $(\mathrm{mm})$, maturity level of male), and fisheries data (characteristics of fish landing place, fishing techniques, fishing duration, fishing ground, catch composition). For species identification the guide book of Last \& Stevens (1994) and White et al. (2006) was used. In addition, catch data for shark were also obtained from daily records filled by TPI officers in Tanjungluar between 2009 and 2010.

\section{RESULTS}

\section{Characteristics of Fish Landing Place}

Tanjungluar is a fishing port located in East Lombok, West Nusa Tenggara where surface and bottom longlines are the main fishing gears used by fishers. Most of fishers normally operate surface longlines almost the whole year, but the peak of fishing occurs from June to September. Bottom longlines are operated by fishers from East Lombok based at Maringkik island, a small island located nearby Tanjungluar. All shark catches landed were sold through an auction. The winner of the auction then takes the fins and sell the meat to the collectors. The sharks are normally processed and sold as fresh meat (or grilled fish) or dried product (salted fish). This fishery targets sharks primarily for their fins, but all sharks are landed whole into the market place and almost all parts are utilised. Fishers use gill nets to obtain bait, typically skipjack tuna (Katsuwonis pelamis), for use on the longlines. The longline fishery consists of vessels operating drift longlines (pelagic) and vessels operating bottom set longlines. Landings occur between 6 am and 8 am every day with all sharks being brought into a covered area and lined up according to the boat by which they were caught. After $8 \mathrm{am}$, each boat's catch is sold by auction and if sold, processors commence processing of the sharks immediately. Fins are removed first, then the trunk is cut in half longitudinally and cartilage, flesh and skin are separated into piles.

In certain time of the year between December March, some tuna vessels from Sulawesi (ex Taiwan) stopover at the Tanjung luar fish landing port to sell their shark catches direct to the buyers without going into auction process.

\section{Fishing Gear}

Description, specification and operating techniques of surface and bottom longlines are as follows:

\section{Shark Surface Longline}

Shark surface longline consists of main line, branch line, hook and float. The line materials are nylon with main line and branch line of $1.000-1.500$ $\mathrm{m}$ and $15 \mathrm{~m}$ with diameter of $6 \mathrm{~mm}$ and $5 \mathrm{~mm}$, respectively, and hook no. 6-7. The number of branch line equals to the number of hooks, i.e. 500 , with of the distance of $30 \mathrm{~m}$ between 2 branch lines.

Shark surface longline is operated by vessel with the dimension of length, width and depth are $15 \mathrm{mx}$ $1,5 \times 1 \mathrm{~m}$, respectively, and weight $7-10 \mathrm{GT}$. This fishing vessel has two mechines (30 HP each) with capacity $10-20$ ton. One unit of vessel has 3 crews and 1 captain. Transportation from the departure location to fishing ground spends 1 day and overnight, whereas from the fishing ground to the Tanjungluar fish landing site needs 3 days and 3 nights. This is due to the targeted fishing ground has moved farther distances. Shift of fishing ground influences fishing duration (in time) in the sea. For example, duration of fishing operation in $1995-2000$ required $5-10$ days, whereas in the last decade up to 2011, it became longer, i.e. $20-25$ days including travel time to fishing ground. This was confirmed by information from fishers in Tanjungluar, who complaint that it is more difficult to catch shark nowadays (Captein Abdul Rahim, September 2011, pers. com.).

Fishers have to catch bait by themselves. Catching bait normally takes $5-6$ days. Fishing is conducted in the morning up to late afternoon by using surface gill net. Several pelagic species were caught, however, frigate tuna and some other baby tuna are more oftenly used as bait. These species are preferred by shark compared to other pelagic fish species. Fishing activity for shark was normally done from the night time and ended in the morning. Setting of shark longline was done from $16.00-17.00$ and hauling was done in the following day from $06.00-09.00$.

\section{Fishing Ground}

Fishing ground of the longline fisheries is presented in Figure 1. The surface longline vessels operate in the off-shore at depths greater than $200 \mathrm{~m}$ to $3000 \mathrm{~m}$. Their fishing grounds are located around Sawu Sea waters to the waters near the border waters of Indonesia-Australia. Whereas fishing grounds of the bottom longline were in the waters around Sumba island, Sawu sea, Ramo island (East Nusa Tenggara), Selura island (South Sumba). 

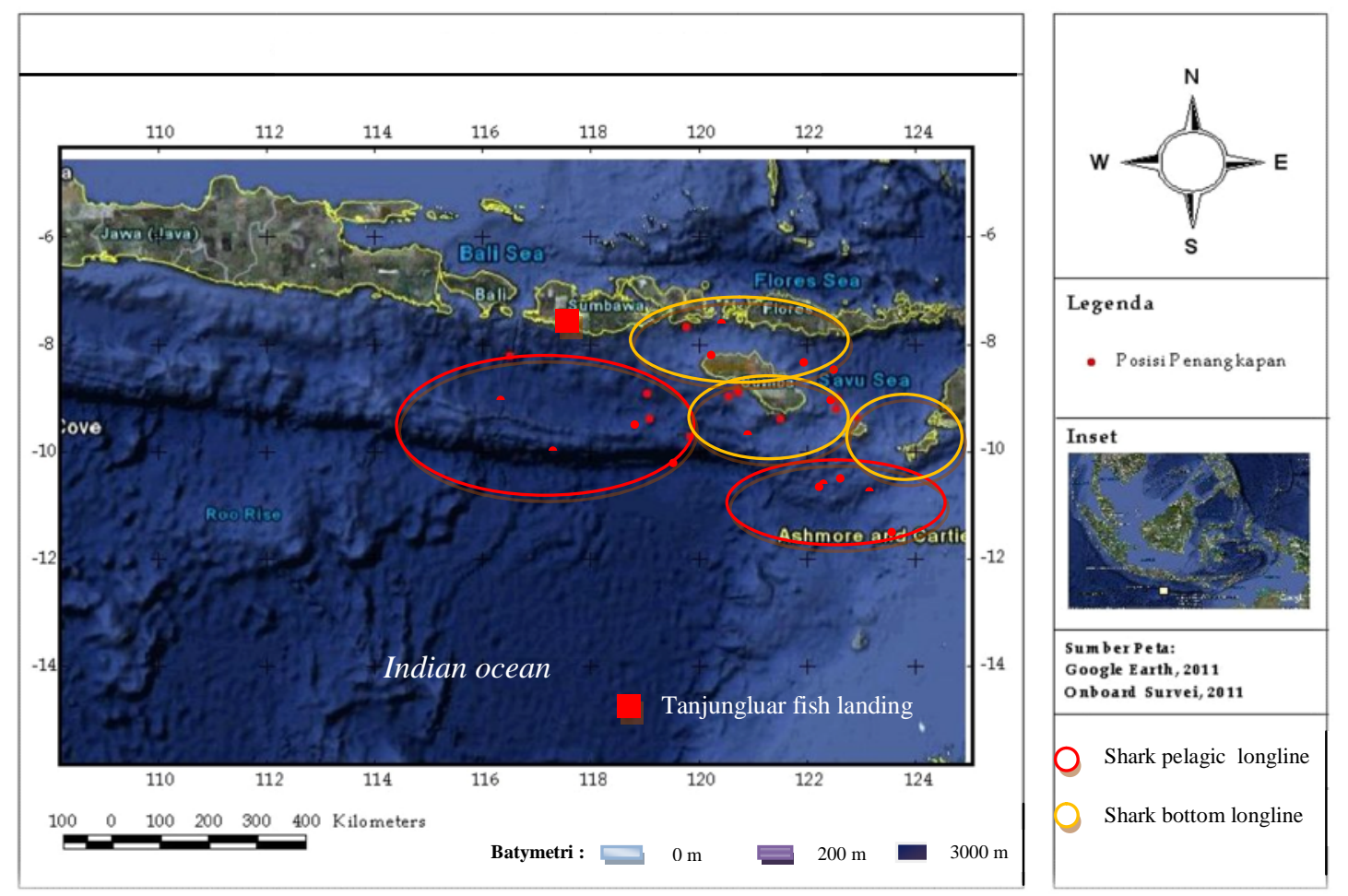

Figure 1. Fishing area of shark longline fisheries

\section{Bottom Shark Longline}

Specification of bottom shark longline consisted of main line made of nylon with diameter of $6 \mathrm{~mm}$ and length of $300 \mathrm{~m}$, and 25 branch lines with diameter of $5 \mathrm{~mm}$ and length of $50 \mathrm{~m}$ (each branch line). The number of hooks is adjusted with the number of branch line. The hook is made of stainless steel, i.e. hook no. 1. Each bottom shark longline vessel has 5 baskets which each basket contains 25 hooks. The bottom shark longline is operated by using wooden boat, with the length of $14 \mathrm{~m}$, width of $1 \mathrm{~m}$ and depth of $1 \mathrm{~m}$, and supported by two engines (25 HP each). One unit of vessel is operated by 4 crews and 1 captain. The bait used are frigate tuna, spanish mackerel and anchovy. The bait fish is were caught by net fishing. Fishing for bait is conducted during the day. The longline gear is then set in the late afternoon between $5-6 \mathrm{pm}$ and set in the water with the depth of $40-50 \mathrm{~m}$ in surrounding Sumbawa island, eastward of Sumba island. Hauling is carried out in the following day at 7 am. From 2000-2005, shark fishing was done for 7-12 days with a normal catch of 10-20 fish. But since 2006, fishing operation had increased to 10-14 days with less fish caught (4-5 fish). The fishers spent 2 days to reach the fishing ground from Maringkik island which serves as the basis of the shark longline fisher group.

\section{Monthly Catch}

The average of shark catch landed monthly by various gears (bottom longline, surface longline, tuna net, and tuna longline) is presented by Figure 2. While, average daily landings for each month using the market survey data for 10 years combined (2001-2011) showed in Table 1.

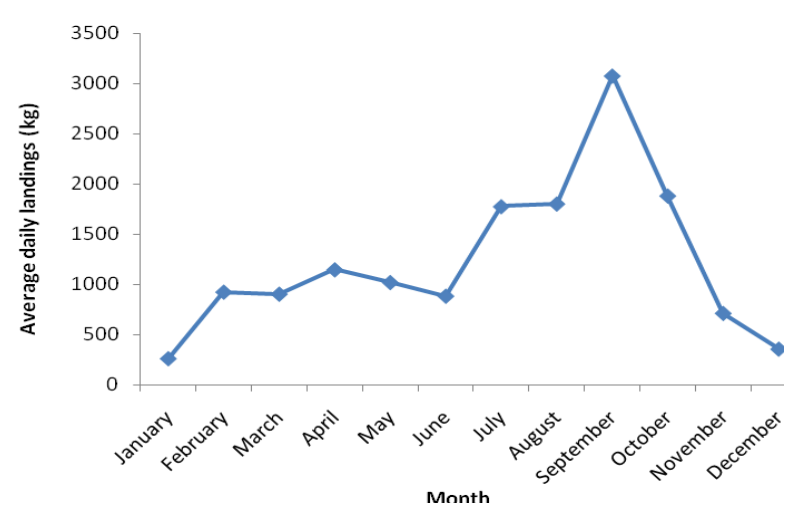

Figure 2. Catch fluctuation of shark based on daily average landing from combained data during 10 years (2001-2010) 
Table 1. Average daily landings for each month using the market survey data for 10 years combined (2001-2011).

\begin{tabular}{lccc}
\hline Month & $\begin{array}{c}\text { Number } \\
\text { of survey } \\
\text { days }\end{array}$ & $\begin{array}{c}\text { Total observed } \\
\text { landings (kgs) }\end{array}$ & $\begin{array}{c}\text { Average } \\
\text { landings } \\
\text { per day (kgs) }\end{array}$ \\
\hline January & 4 & 1055.1 & 263.8 \\
February & 2 & 1852.6 & 926.3 \\
March & 12 & 10872.1 & 906.0 \\
April & 5 & 5742.6 & 1148.5 \\
May & 4 & 4087.0 & 1021.8 \\
June & 3 & 2658.0 & 886.0 \\
July & 9 & 15994.1 & 1777.1 \\
August & 11 & 19841.1 & 1803.7 \\
September & 8 & 24618.5 & 3077.3 \\
October & 13 & 24485.0 & 1883.5 \\
November & 4 & 2857.2 & 714.3 \\
December & 4 & 1435.8 & 358.9 \\
\hline
\end{tabular}

\section{Number of species by family}

Sharks caught by surface longline were generally pelagic shark group from the following families: Carcharhinidae, Lamnidae and Alopiidae. These families live in mesopelagic zone with the depth between 200 to $1.000 \mathrm{~m}$ (Camhi et al., 2007).

On the other hand, bottom longline catches sharks that live in the bottom waters and some species of ray from families Rhynchobatidae, Rhinidae, and Dasyatidae. The number of shark and ray species by individual family caught by surface and bottom longline is presented in Figure 3.

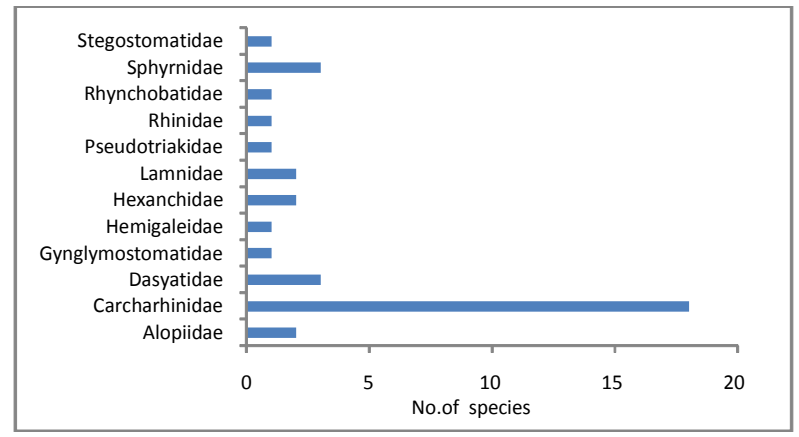

Figure 3. Number of species by family from the shark longline fishery at Tanjungluar.

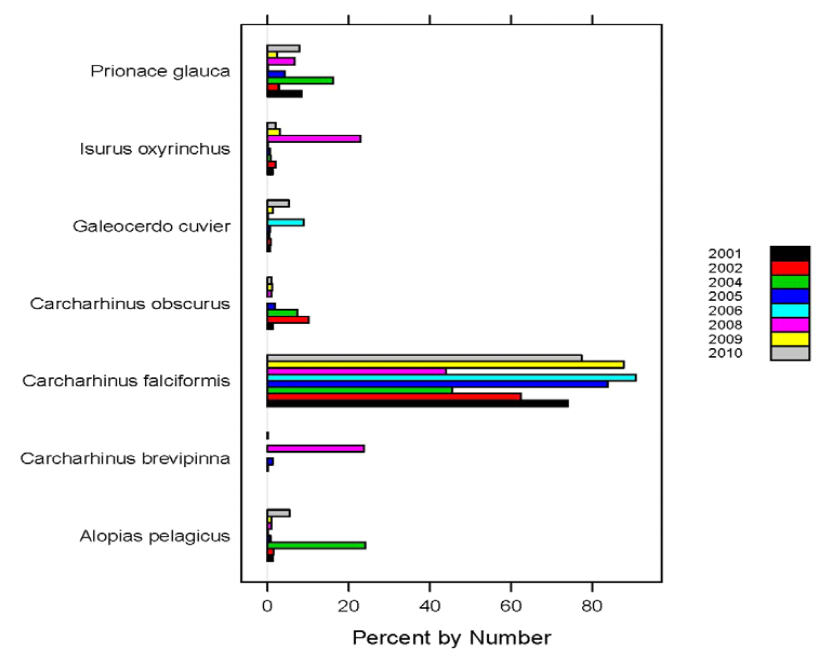

Figure 4. Annual trends of catch by number of species (\%) of the surface longline.

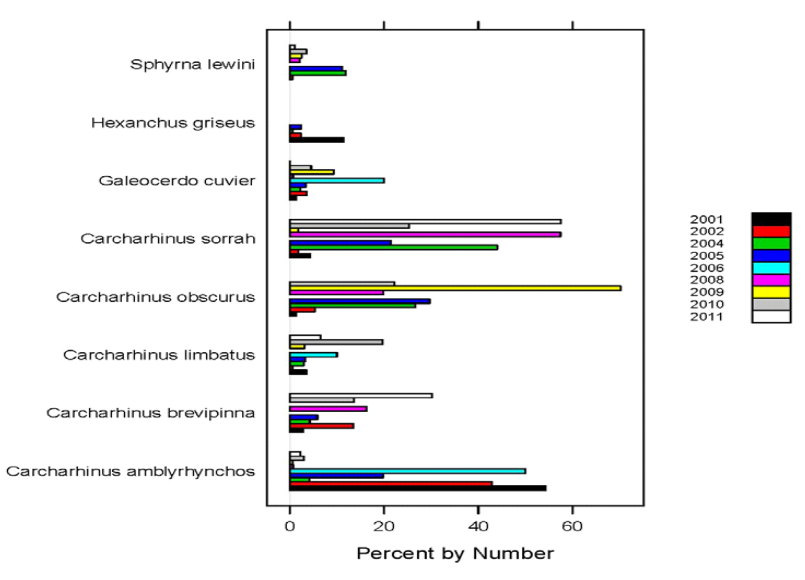

Figure 5. Annual trends of catch by number of species (\%) of the bottom longline.

\section{Dominant Shark Catches}

The dominant shark species caught by surface and bottom longlines, size of the shark caught and conservation status are presented in Table 2 and 3. Species of dominant sharks caught by those longlines showed in Figure 6 and 7. 
Table 2. Size of dominant shark caught by surface longline and its conservation status

\begin{tabular}{|c|c|c|c|}
\hline \multirow[b]{2}{*}{ Species } & \multicolumn{2}{|c|}{ Shark caught by size $(\mathrm{cm})$} & \multirow{2}{*}{$\begin{array}{c}\text { Conservation status (IUCN } \\
2006 ; 2009)\end{array}$} \\
\hline & Immature (\%) & Mature (\%) & \\
\hline Alopias pelagicus & $150-270(46)$ & $250-350(54,0)$ & Vulnerable to extinction \\
\hline Carcharhinus brevipinna & $50-190(60,4)$ & $200-300(39,6)$ & Near threatened \\
\hline Carcharhinus falciformis & $100-215(75,9)$ & $220-250(24,1)$ & Least concerned \\
\hline Carcharhinus obscurus & $200-270(92,9)$ & $290-300(7,1)$ & Near threatened \\
\hline Galeocerdo cuvier & $130-310(95,8)$ & $350-380(4,2)$ & Near threatened \\
\hline Isurus oxyrhynchus & $100-250(58,6)$ & $200-260(41,4)$ & Near threatened \\
\hline Prionace glauca & $200-210(6,1)$ & $210-300(93,9)$ & Near threatened \\
\hline
\end{tabular}

Table 3. Size of dominat shark caught by bottom longline and its conservation status

\begin{tabular}{|c|c|c|c|}
\hline \multirow[b]{2}{*}{ Spesies } & \multicolumn{2}{|c|}{ Size of shark caught $(\mathrm{cm})$} & \multirow{2}{*}{$\begin{array}{l}\text { Conservation status } \\
\text { (IUCN, 2006; 2009) }\end{array}$} \\
\hline & Immature (\%) & Mature (\%) & \\
\hline Carcharhinus amblyrhynchos & $75-125(17)$ & $125-200(83)$ & Near threatened \\
\hline Carcharhinus limbatus & $60-180(34)$ & $170-250(66)$ & Near threatened \\
\hline Carcharhinus sorrah & $80-110(36)$ & $100-150(64)$ & Not evaluated \\
\hline Hexanchus griceus & $200-375(85)$ & $310-480(15)$ & Near threatened \\
\hline Sphyrna lewini & $100-225(42)$ & $170-300(58)$ & Near threatened \\
\hline
\end{tabular}

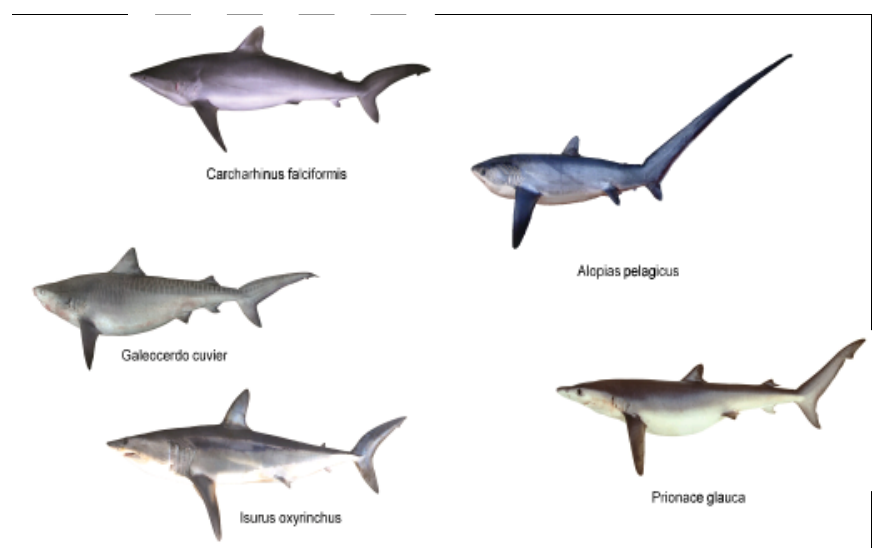

Figure 6. Species of dominant sharks caught by surface longline

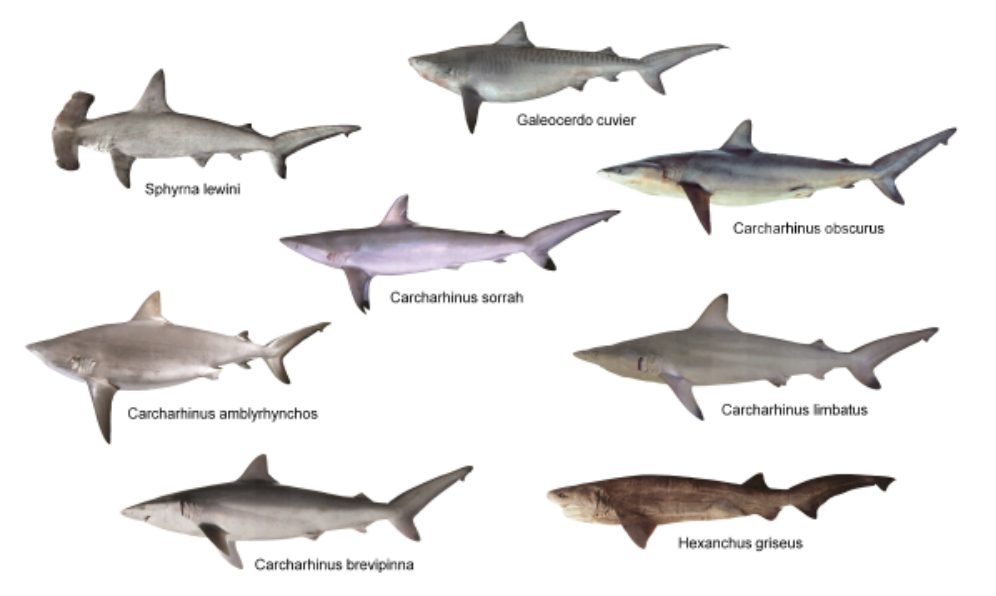

Figure 7. Species of dominant sharks caught by bottom longline 


\section{DISCUSSION}

Interviews with fishers operating bottom shark longline, indicated that between 1994-1998, their fishing grounds include waters of Teluk Campi, Datuk island up to boundary waters of Australia, they caught $100-200$ sharks that was dominated by Prionace glauca (hiu karet or hiu slendang). However, between 1999 and 2008, the fishing grounds moved to other waters such as Sumba, Sabu and Rote islands with the catch between 20-50 fish consisted of several shark species. Recently, shark catches by fishers based at Tanjungluar decreased relative to the previous years. Fishing activities normally increase between June and September. During the peak season, fishers only need 12-14 days at sea. Whereas during west season (January-March) fishing activities decreased, only 23 vessels were in operation, normally only fishers from Bugis-North Celebes. This was due to bad weather condition (caused by rough wind and big wave).

Fishing activity of bottom shark longline takes the whole year except during the bad weather. Catches of bottom shark longline were relatively stable from year to year between 5-10 fish per trip. Several shark and ray species that were rarely caught from 20002011, i.e. Rhynchobatus sp (hiu panrung), Squalus spp., Centrophorus spp. (hiu botol) (Captein Asrul, September 2011, pers. com.). These species were listed as vulnerable to extinction under IUCN (2006). There are some vulnerable shark species caught in the Indian Ocean from 2001-2005, i.e. Isurus paucus, Isurus oxyrhynchus (hiu mako, hiu tenggiri), Carcharhinus longimanus (hiu koboi), and Centrophorus squamosus (hiu botol). Those species were mostly found in the condition of adult mature size (Dharmadi et al.,2012).

Shark fishing activities in Tanjungluar occurr every month. The monthly catches of shark fluctuated, but from July to October the catches were within the range of 15,9-24,5 tonnes (Table 1). These catch levels were higher than the catches before July and after October, with the peak occurred in September (24,6 tonnes). The trend of shark catches relates to the number of fishing vessels, fishing ground, and weather conditions at sea. The period between July and September is a transitional season from East to West seasons. During this season, the wind strength is weakened and serves as a good fishing season for the fishers.

There are 12 families of shark and ray caught by both surface and bottom longlines, with the most dominant group were from family Carcharhinidae, i.e. 18 species. Other studies indicated that within the artisanal shark fishery in the Eastern Indonesian waters, the domination of family Carcharhinidae reached to $60 \%$ (White et al., 2006b; White, 2007). On the other hand, survey conducted in 2001-2010 indicated that catches of surface longlines were dominated by Silky shark (Carcharhinus falciformis) with the percentage of $40-90 \%$ (Figure 4). Amande et al. (2008) stated that in the Western Indian Ocean Silky shark were frequently caught as by-catch by purse seine between July and September. In addition, $85 \%$ of the catches were in immature condition or small size and were discarded to the sea, only $15 \%$ of the catches were retained by the fishers as their additional income or for consumption. Some experts reported that shark species predominantly caught in the Western Pacific Ocean was Silky shark, 70-80\% of the total catch (Anderson \& hafiz et al., 1997), while purse seine contributed $25 \%$ of the catches in the Pacific Ocean (Oshitani et al. (2003). In the waters of Southern part of Java, $66,4 \%$ of Silky shark catches were still young, with the size of $50-170 \mathrm{~cm}$ (Dharmadi \& Fahmi, 2007). Whereas in the Western part of Indonesian waters, almost $50 \%$ of Silky shark catches were in immature condition ( $<1400 \mathrm{~mm} \mathrm{TL})$ and $<5 \%$ were juvenile (Fahmi \& Sumadhiharga, 2007).

The catch of bottom longline consists of 8 species of 3 families, i.e. Sphyrnidae, Hexanchidae, dan Carcharhinidae (Figure 5). Only 3 species of sharks dominated the catches of bottom longline from 20012010, i.e. Spot-tail shark (Carcharhinus sorrah), Dusky whaler ( $C$. obscurus) and Grey reef shark ( $C$. amblyrhynchos).

Several shark species of Carcharhinidae (Carcharhinus brevipinna, C. falciformis, C. obscurus, Galeocerdo cuvier, dan Isurus oxyrinchus) caught were (58-96\%) in immature condition (Table 2). Meanwhile, Prionace glauca (Blue shark) were caught more on the adult size up to mature condition (93,9\%). In terms of conservation status, those species population are threatened to extinction (IUCN, 2006; 2009). More than $50 \%$ of the Alopias pelagicus (Pelagic thresher shark) catches were adult-sized up to mature $(250-350 \mathrm{~cm})$ with the conservation status of being vulnerable to extinction (IUCN, 2006; 2009). On the other hand, the dominant sharks caught by bottom longline were mostly in mature condition except Hexanchus griceus (Table 3). These species belong to vulnerable to extinction status are Carcharhinus amblyrhynchos, Carcharhinus limbatus (Silky shark), Hexanchus griceus (Bluntnose sixgill shark), and Sphyrna lewini (Sclloped hammerhead) (IUCN, 2006; 2009). One of those species (S. lewini) was listed in appendix II of the IUCN, in the 16th Conference of the Parties (CoP16) in 2013. 


\section{CONCLUSION}

1. Fishing activity for shark in Tanjungluar occurs across the whole year. The lowest catch of shark landed occurs in January $(1.055,1 \mathrm{~kg})$ and the highest was in September $(2.4618,5 \mathrm{~kg})$

2. Fishing grounds for bottom longline are in the waters around Sumba island, Sawu sea, Ramo island (East Nusa Tenggara), Selura island (South of Sumba) in the depth between 50-100 m. Surface longline vessels operated in the offshore waters near the Eastern part of the Indian Ocean down to the waters near the boarder between Indonesia and Australia.

3. Catch of shark surface longline was dominated by Silky shark (Carcharhinus falciformis) whereby most of them were in immature condition. Whereas bottom longline catch was dominated by families of Carcharhinidae (Carcharhinus amblyhynchos, C. limbatus, C. sorrah), Hexanchidae (Hexanchus griceus), and Sphyrnidae (Sphyrna lewini). These shark species were caught in mature condition.

\section{ACKNOWLEDGEMENTS}

This research is a collaborative project between RCFMC (Research Center for Fisheries Management and Conservation), University of Wollongong and CSIRO. It was funded by ACIAR under the project : "Developing New Assessment and Policy Frameworks for Indonesia's Marine Fisheries, Including the control and Management of Illegal, Unregulated and Unreported (IUU) Fishing".

\section{REFERENCES}

Amande, M.J.; Chassot E,; Chavance P., \& R. Pianet. 2008. Silky shark (Carcharhinus falciformis) bycatch in the French tuna purse-seine fishery of the Indian Ocean. IOTC WPEB - 2008/016.

Anderson,R.C \& A.Hafiz. 1997. Elasmobranch Fisheries in the Maldives. in Elasmobranches Biodiversity, Conservation and Management. Proceedings of the International Seminar and Workshop, Sabah, Malaysia, July 1997. Occasional paper of the IUCN Species Survival Commissions No. 25. p. 114-121.

Blaber, S.J.M. 2006. Artisanal shark and ray fisheries in Eastern Indonesia: their socioeconomic and fisheries characteristics and relationship with
Australian resources. ACIAR PROJECT FIS/2003/ 037 supplementary stock assessment meeting, CSIRO Cleveland, Australia, 4 September, 2006. $57 \mathrm{p}$.

Blaber, S.J.M.,C.M. Dixhmont, W.White, R.Buckworth, L. Sadiyah, B. Iskandar, S. Nurhakim, R. Pillans, R. Andamari, Dharmadi, \& Fahmi. 2009. Elasmobranchs in southern Indonesia fisheries: the fisheries, the status of the stocks and management options. Rev. Fish Biol. Fisheries. Research paper. Published online:03 February 2009. Springer Science+Business Media B.V. $25 \mathrm{p}$.

Bonfil, R. 2008. The biology and ecology of the silky shark, Carcharhinus falciformis. Pp. 114-127. In: Sharks of the Open Ocean: Biology, Fisheries and Conservation (eds M.D. Camhi, E.K. Pikitch and E.A. Babcock). BlackwellPublishing, Oxford, UK.

Camhi M.D, Sarah V. Valenti, Sonja V. Fordham, Sarah L. Fowler \& Claudine Gibson. 2007. The Conservation Status of Pelagic Sharks and Rays Report of the IUCN Shark Specialist Group Pelagic Shark Red List Workshop Tubney House, University of Oxford, UK, 19-23 February 2007. $78 \mathrm{p}$.

Castro, J.I; C.M Woodley, \& R.L. Brudek. 1999. A Preliminary Evolution of the Status of Shark Species. National Oceanographic and Atmospheric Administration. National Marine Fisheries Service Southeast Fisheries Science Center Miami, Florida, USA, FAO. Fisheries Technical Paper No. 380.

Davenport, S. \& Stevens, J.D. 1988. Age and growth of two commercially important sharks (Carcharhinus tilstoni and C. sorrah) from northern Australia. Australian Journal of Marine and Freshwater Research 39: 417-433.

Dharmadi \& Fahmi. 2007. Length distribution, total and clasper length relationship and sex ratio of silky shark (C. falciformis). JPPI 13, (3). PRPTBRKP. (in bahasa).

Dharmadi, Fahmi, \& N.N. Wiadnyana. 2012. Identification of Vulnerable Species and Biological of Sharks from the Indian Ocean. Proceeding of the 7th International Symposium of SEASTAR2000 and ASIAN Biologging Science (The 11th SEASTAR2000 Workshop), March 8-9, 2011, Bangkok. Thailand. $67 \mathrm{p}$. 
Fahmi \& Sumadhiharga, O.K. 2007. Size, sex and length at maturity of four common sharks caught from Western Indonesia. Mar. Res. Indonesia. 32, (1), 2007: 7-19.

Fowler, S.L., Reed, T.M. \& Dipper, F.A. (eds). 2002. Elasmobranch Biodiversity, Conservation and Management: Proceedings of the International Seminar and Workshop, Sabah, Malaysia, July 1997. IUCN/SSC Shark Specialist Group. IUCN, Gland, Switzerland and Cambridge, UK. xv + 258 p.

IUCN. 2006. Release of the 2006 IUCN Red List of threatened species reveals ongoing decline of the status of plants and animals. IUCN Press Release, 2 May 2006. http://www.iucn.org/en/news/archive/ 2006/05 pr red list en.htm.

IUCN. 2009. About the IUCN Red List. At cms.iucn.org/about/work/programmes/species/ red_list about/work/programmes/species/red_list/ about the red_list/. Accessed 10 Nopember 2010.

Last, P.R. \& J.D. Stevens. 1994. Sharks and Rays of Australia. Fisheries Research and Development Corporation.

Lack, M., \& G. Sant. 2011. The Future of Sharks : A Review of Action and Inaction. TRAFFIC International and the Pew Environment Group. Washington, D.C. January 2001. 41 p.

Oshitani, S; H. Nakano \& S. Tanaka. 2003. Age and growth of the silky shark Carcharhinus falciformis from the Pacific Ocean. Fisheries Science: 2003:69:456-464.
Sedana, I.G. 2004. Musim Penangkapan Ikan di Indonesia. Balai Riset Perikanan Laut. Pusat Riset Perikanan Tangkap. BRKP-DKP. Jakarta. 116 p.

Sylvana, V.D.M; G. Caille \& R. Gonzales. 1998. Bycatch of sharks in Patagonian coastal trawls fisheries. Mar. Freshwater Res. Argentina, 1998, 49, 641- 4 .

Steven J.D., Bonfil R., Dulvy N.K. \& P.A. Walker. 2000. The effects of fishing on sharks, rays and chimaeras (chondrichthyans), and the implications for marine ecosystems. ICES J. Mar. Sci., 57: 476-494.

White, W.T., P.R. Last, J.D. Stevens, G.K. Yearsley, Fahmi \& Dharmadi. 2006. Economically Important Sharks and Rays of Indonesia. National Library of Australia Cataloging-in-Publication entry . Australia. 329 p.

White, W. T., Giles, J., Dharmadi \& Potter, I. C. 2006b. Data on the bycatch fishery and reproductive biology of mobulid rays (Myliobatiformes) in Indonesia. Fisheries Research 82, 65-73.

White, W. T. 2007. Catch composition and reproductive biology of whaler sharks (Carcharhiniformes: Carcharhinidae) caught by fisheries in Indonesia. Journal of Fish Biology 71, 1512-1540.

Zainudin, I.M. 2011. Pengelolaan Perikanan Hiu Berbasis Ekosistem di Indonesia. Thesis Pasca Sarjana. Universitas Indonesia, Depok. 93 p. 